\title{
The Effect of Customer Loyalty Programs on Customer Retention in Pakistan
}

\author{
SYED MAJID KHALIL \\ MS Research Scholar, Abasyn University, Peshawar \\ OBAID ULLAH \\ MS Research Scholar, Institute of Business Studies and Leadership \\ Abdul Wali Khan University, Mardan \\ DR. SYED HAIDER KHALIL \\ Assistant Professor, Institute of Business Studies and Leadership \\ Abdul Wali Khan University, Mardana
}

\begin{abstract}
The aim of our study was to build an extremely significant understanding of the influence of client's loyalty programs on buyer's retention. The context of the current study was set for Pakistani consumers. The current study inspects the key role of loyalty programs such as devotion programs, point framework, level reward framework and non-fiscal projects on the dependent variable: client retention. A quantitative analysis method was adopted to achieve the objective of the research. For the data collection, questionnaires were distributed randomly among customers. Our findings suggest that there is a significant impact of loyalty programs for retaining valuable customers. Evidently, a significant effect was noted for different types of loyalty schemes such as Tier reward, Point and Non-monetary schemes.
\end{abstract}

Keywords: Loyalty programs, point program, tier reward program, non-monetary schemes and customer retention

\section{Introduction}

The function of consumer loyalty in a business's operations has been widely debated among researchers. A prior study suggests that there is a positive connection between customer loyalty and success (Hofman-kohlmeyer 2016). Corporations are struggling to create long-term relations with clients as the spirits of attachment results in making high revenues (Hofman-kohlmeyer 2016). Effective loyalty programs are helpful in converting a 'delighted' client to a 'loyal' one, which shields market dividends for a long period (Vinod 2011). Tabaku and Mersini (2015) explained consumer loyalty by two ways: behavioural and emotional. In behavioural loyalty the customer regularly and repeatedly purchasing from same seller and emotional loyalty is an outcome of a psychosomatic linking with the service or product relating a preferences and components like an encouraging attitude and commitment. Udin and Hizza (2014) concluded that customer loyalty is an unceasing affiliation amongst the brand and customer. Hofman-kohlmeyer (2016) argued that customer loyalty acts as a resistance in switching brands despite problems come across during the business process. They further described customer loyalty as a regular purchasing from one store/brand (Hofman-kohlmeyer, 2016). Loyalty programs results in continuous buying, attracting more clients and less price negotiations (Neira, Vázquez \& Iglesias 2010). Devoted clients play even a great role in minimizing advertising and promotional 
expenses over extended period (Mascarenhas, Kesavan \& Bernacchi 2006). There is a plethora of evidences that identified key factors of developing loyalty among customers. Garcia et al. (2006) defined the term satisfaction as "An evaluation of the perceived discrepancy between prior expectation and the actual performance of the product". With respect to services, satisfaction a customer perceiving is closely related to affirmation or dis-affirmation of desires (Garcia et al. 2006). Permanent endearment towards a question, object or the way you feel about something known as attitude. Constructive attitude is very helpful for developing loyalty (Garcia et al. 2006). Commitment is the outcome of a balanced and emotional link in relations. Several authors argued that in the absence of emotional aspects there will be no customer loyalty. Repetitive interactions with customer is not sufficient to make them loyal (Garcia et al. 2006). Trust plays great role in making loyal customers. Retailers must provide correct information to customers for gaining loyalty in return. So, a service or product provider must confirm that confidential data is communicated (Garcia et al. 2006). Summarising our above discussion, we can argue that satisfaction, attitude, commitment and trust are the key factors for constructing loyalty among valuable customers.

Customer loyalty is a non-avoidable problem in any corporation's success, evidently bringing new customers is a costly affair than retaining existing customers (Singh \& Khan 2012). A recent study suggested that loyalty schemes have a positive impact on customer retention in Jordanian market (Magatef \& Tomalieh 2015). To retain old customers, they investigated variables such as point system, loyalty card system and non-monetary schemes in Jordanian market. With differences in the norms, culture, and buying behaviour and purchase patterns, it is still not clear if their findings are acceptable in other parts of the world, such as Pakistan, and with what consequences? Based on their study, the current study attempted to explain the influences of these loyalty programs from the context of Pakistan and examined if these variables have positive or negative impact on customer retention.

The purpose of our study is thus to examine the influence of loyalty schemes on customer retention in Pakistan. The current investigation critically examines the below sub objectives to achieve the overall aim of our study.

1. Examine the influence of loyalty card scheme on customer retention in Pakistan.

2. Examine the influence of point system on customer retention.

3. Examine the influence of non-monetary schemes on customer retention.

4. Examine the influence of Tier reward system on customer retention.

\section{Review of Literature}

\subsection{Customer Loyalty Program}

In recent years, marketers showed renewed interest in customer loyalty programs that signifies the importance of customer relationship (Solarova 2015). Their study further suggests that rewards and loyalty programs are developed to satisfy customer needs and desires using cash value, enhancement possibilities, aspirational cost, importance and suitability (Dowling \& Uncles 1997). The influence of loyalty programs differs depending on customer's participation. In high participation conditions, secondary returns on purchases are more visible than the instant rewards whereas in the less participation conditions, instant compensations on purchases are more helpful in constructing the value for loyalty programs when compared against late reward (Uncles, Dowling \& Hammond, 2003). Jain and Singhal (2012) concluded that in spite of the predominant use of loyalty programs, there is inadequate affirmation on 
the long-standing effects of these programs, and their efficiency is not well recognized. Customer loyalty can be described as 'retention with attitude' where loyalty can be termed as an attitude (Magatef \& Tomalieh, 2015). Byron and Sharp (1997) analysed individual-level data by using a one-time converting model to test the capability of a loyalty program to modify usual repetitive buying ratio, however; their findings were largely contested among researchers and marketing experts. Drèzea and Hoch (1998) reported on a group of specific loyalty program that caused an increase in both specified group and overall store traffic. Loyalty programs as a consequnce compensate customers for consolidating their consumptions (Karim, 2011). The 'equity' that the purchaser creates through collecting points, focuses to involve clients in the loyalty program (Sharp \& Sharp, 1997). Retailers are looking for methods of getting competitive benefits and well-managing relationships with customers (Karim, 2011). Institutions found loyalty systems very helpful in distinguishing their customers and recognizing their buying behaviours by gathering adequate information for analysing their customers (Vyas \& Sinha 2008).

Rowley (2000) suggested that loyalty programs are the recognized quality of the marketing industry. Loyalty programs had become extensive and questionably 'ubiquitous' (Rowley, 2000). Wright and Sparks (1999) concluded that in retail industry, corporation with 'first mover' benefit and developed loyalty programs, tried to govern the loyalty card users. As the dormant for surplus reinforces in marketplaces, businesses must differentiate or modify their card subscription (Wright $\&$ Sparks, 1999). Businesses have to deliver clients with an extra motive or advantage for holding the loyalty card (Wright \& Sparks, 1999). Brien and Jones (1995) in their study concluded that several rewards and loyalty programs in the marketplace today reveal a limited information of a client wants and needs. Brien and Jones (1995) recommend that comparative worth of reward and the probability of attaining that reward are the main reasons that a purchaser consider before engaging in a loyalty program. Brien and Jones (1995) further argued that reward systems may emphasise on increasing purchase limits and time limits but it also constructs a positive effect on customer's behaviour and assessment. Susan (1995) suggested that loyalty programs that reward customers will help in increasing affiliation intervals and consumption stages, after that consumer will be gradually acknowledged to the whole variety of facilities (Keaveney, 1995). Amplified customer contentment has a constructive effect on economic operations and the constructive economic conclusions of the loyalty reward system exceeds the resources invested in the loyalty schemes (Anderson, Fornell \& Lehmann, 1994). Deighton (2000) argued that expertise allows businesses to exercise individualist marketing which support the globalisation of loyalty schemes into numerous businesses such as, gaming, monetary facilities, and marketing expertise to examine the circumstances where the loyalty reward schemes will have a constructive impact on client valuations, conduct, and repeat buying intents. The firms that provided tier reward systems to their clients practiced time series and cross-sectional data (Bolton, Kannan \& Bramlett 2000).

sBolton et al. (2000) argued that 'Tier incentives schemes' are highly significant for retaining customers. They presented a model, which intends to examine the efficiency of a Tier reward system for customer retention (Bolton et al., 2000). Lewis (2004) looked into the 'customer's reaction to a loyalty program' and linking it to discretechoice and self-motivated program strategy. Omar, Azrin and Sarah (2009) suggested that customer relationship marketing tools have evolved over the years and became highly significant for organisations. Today, Loyalty schemes are frequently used 
within organisations as it maximises profits and helps in attracting customers, generating sales, and retaining customers (Omar et al., 2009). Waarden (2006) suggested the factors that cause high substituting cost includes emotional, social and interpersonal motives but develops customers' trust, emotional commitment and loyalty to the corporation. Waarden (2006) recommended that loyalty programs can potentially create a sense of belongingness and prestige. It constructs a feeling of gratitude among clients and consider themselves as an exclusive customer when they compare benefits of loyalty program. Summarising the argument, we can say that loyalty programs can be seen as 'strategic marketing tools' that are used to achieve client's heterogeneity by choosing, recognizing and grouping customers to maximise profit and customer retention.

\subsection{Customer Retention}

Ranaweera and Prabhu (2003) defined customer retention as 'the tendency of a customer to stay with the service provider and therefore is viewed as a behavioural factor'. To make a customer to behave in a certain way is formed by offering them the services they are expecting from the company (Ranaweera \& Prabhu, 2003). Customer retention is critical for business success as it assure that the customers will remain loyal for a longer period of time (Aronkar, Jauhari, Bhakar \& Lal, 2015). Evidently, customers can be satisfied in the service sector through quality and it becomes an important component of customer retention startegy (Ali \& Rehman, 2010).) Customer can be considered as 'retained' when they make a repeat purchase and it will depend on the excellence of services offered to the consumer (Anderson et al., 1994). Retaining customers has become an important issue and it has a strong impact on market growth (Steenkamp, 1989).

There is a plethora of evidences which confirms the significance of customer retention. Barnes (1997) found that loyal customers keep recommending to more customers which help the organisations to acquire more new customers. Gerpott, Rams and Schindler (2001) found that in business-to-business marketing relationships between customers and organisations is the primary cause of customer retentions. Lin $\& \mathrm{Wu}(2011)$ concluded that relationship marketing helps retain existing customers. Rust, Zahorik \& Keiningham (1995) found that attraction and retentions of customer remain treated as an element for increasing profitability of a firm. Saeed, Grover and Hwang (2005) argued that to retain customers, it is crucial for the company to understand how to treat their customers and offer after sale facilities. Lin and $\mathrm{Wu}$ (2011) found that customer retention is influenced by the future use of the product. Verhoef (2003) inspected and found that loyalty programs that offer monetary benefits are more effective in retaining customers. Yang and Peterson (2004) found a significant relationship between customer loyalty and customer retention. Smith \& Chang (2009) found that customer retention can be considered as customer loyalty and it may no impact on customer loyalty. Rust and Zahorik (1993) has found a strong association between the loyalty and retention of customers. Hallowell (1996) argued that retaining customers can be reflected in customer loyalty.

Bolton et al. (2000) concluded that customer loyalty has a positive impact on customer retention. Gerpott et al. (2001) examined the relationship between retaining customers and customer's loyalty and found a positive connection in the retail market. Customer retention was shown a primary goal of relationship marketing in the firms (Aronkar et al. 2015). The main motive for this research is to build up a theoretical framework for inspecting the client upholding process, with the use of the concepts of consumer loyalty and affiliation fineness (Hennig-Thurau \& Alexander 
1997). Hennig-Thurau \& Alexander (1997) concentrated on the purchaser loyalty with a company's item or facilities as it is significant to firm's success and long-haul aggressiveness and considering client's loyalty as a key element of client retention.

\subsection{Loyalty Programs with in the Retail Sector}

Modern loyalty scheme program can be traced back to year 1981 when American Air company presented its frequent flyer scheme and since then, these schemes became popular among institutions and since then, these schemes kept on popping up in rest of the world (Sneath \& Lacey, 2006). Consumer retention strategies are used over a wide range of vertical buyer markets, including lodgings, Mastercard guarantors, retailers, aircrafts, auto-mobile rental organisations and entertaining companies (Karim, 2011). In Germany, more than 100 various loyalty programs and the proportion of relative's participation in a single loyalty program are more than 40 percent. The variety of loyalty programs are more than 400 , and participation of users in these programs is approximately $80 \%$ In the United States of America (Garcia Gomez \& Gutierrez Cillan, 2006). Approximately 97\% Canadian customers possess at least one loyalty card (Sneath \& Lacey, 2006). Organisations and retail businesses in developed countries offering a bunch of loyalty programs to their customers include North America, Australia, the United Kingdom and Europe (Sneath \& Lacey, 2006). Due to internationalisation, marketplace satiety and increased competition through mergers and acquisitions of retail businesses are searching for approaches to achieve competitive benefits and well customer management system (Anderson et al. 1994). In today's competitive environment, retailers and businesses have to establish strong links with their customer. Loyalty programs became a key tool for marketers to establish links with customers and to acquire a better knowledge of their buying behaviours (Wood, 2005).

\subsection{Types of Loyalty program}

2.4.1 Loyalty card program: Loyalty program allows retailers to gather data about their clients. Consumer are provided shopping discounts, vouchers, points to claim any product or other compensation in return for their volunteer participation (Magatef \& Tomalieh, 2015).

H1: Client loyalty programs have a positive effect on customer retention.

2.4.2 Point system. It is commonly used form loyalty program. Regular customers get points, which later converts into rewards like, reduction in price, gifts or superior client handling. Customers buy more to collect more points and cash their points. This type of card is issued by shopping malls or hypermarket to their regular clients, credit points are recorded according to the transactions made in the specific mall (Peiguss, 2012).

H2: Point program has a positive effect on customer retention.

2.4.3 Tier reward system. Tier Reward system offers benefits to the customers by subscribing to the scheme and motivates regular clients by maximizing the worth of the return on purchases as the client shifts to next loyalty rank (Peiguss, 2012).

H3: Tier reward program has a positive effect on customer retention.

2.4.4 Non-monetary schemes. Non-monetary schemes valuing their clients in different ways rather than offering discounts or cash rewards. According to customer's preferences and standards, customers could prefer non-monetary benefits over discounts or cash rewards. The customers in this type of loyalty program are rewarded other than cash. In a non-monetary scheme, the participants of the program are rewarded with gifts or after sale services (Peiguss, 2012).

H4: Non- monetary schemes have a positive effect on customer retention. 


\section{Research Methodology}

Our study utilised the concept of 'Research Onion' presented by Saunders, Lewis, \& Thornhill, (2009). When we look into the objectives set for our study, it aligns with the positivist philosophy and deductive approach (Saunders et al. 2009). Taking a positivist approach, a survey method seemed more appropriate for data collection. The present research is cross-sectional, which means that data was gathered on a single point in time (Bashir 2011). The questionnaire was adapted from a prior study that argued about the impact of loyalty programs on customer retention (Magatef \& Tomalieh 2015). Using a quantitative method, the data was analysed to make meaningful interpretations.

Due to the strong competitive environment in retail industry, retailers provide a lot of loyalty schemes and regular customers schemes to boost the sales of goods via consumer repurchase by some undefined time frame. In spite of the prevalent of loyalty programs in retail industry, there are few empirical studies that stresses on the effect of these loyalty systems on customer retention (Magatef \& Tomalieh 2015). The significance of our study is to measure the influence of loyalty schemes on customer retention in Pakistan, which is relatively an unexplored context.

Loyalty programs boost customers to move from single buying decision to numerous buying decision (Magatef \& Tomalieh 2015). The present research is an effort to examine the effect of loyalty schemes on retaining customers. The major objective of the current study, is to determine customer retention as dependent variable determine by the possibility of suggesting the corporation to customers, the possibility to purchase again, and possibility to shift. Loyalty programs (point program, tier reward program and non-monetary schemes) are the independent variables.

The research addresses the below mentioned queries:

1. How consumer loyalty schemes are affecting customer retention?

2. How point program is affecting customer retention?

3. How tier reward program is affecting customer retention?

4. How non-monetary schemes are affecting customer retention?

\subsection{Research Model}

The purpose of the current research is to achieve a profound comprehension of loyalty programs and it effect on customer retention. The diagram given below demonstrates the proposed research model.

\section{Figure 1}

Theoretical Framework

\section{Independent Variable:}

Loyalty Schemes:

Point program

Tier Reward program

Non-Monitory schemes

Customer Retention:
The possibility of suggesting the
$\mathrm{H} 3 \longrightarrow \begin{aligned} & \text { Thendent Variable: } \\ & \text { corporation to others } \\ & \text { The possibility to purchase again } \\ & \text { Possibility to shift }\end{aligned}$




\subsection{Instruments}

To attain the objectives of the present study, emphasis is made to find primary data by constructing a survey to gather information from the sample. The questionnaire comprises three sections; the first section is about demographical aspects. The second section is about the nature of loyalty card that the consumer owns and the perception of the respondent about the statements about several forms of loyalty schemes. The last section is about the perception of customers regarding various statements of customer retention. Regression, correlation analysis and other relevant tests were used as statistical instruments to find the relationship between dependent and independent variables. We used 'Likert Scale' for measuring the relationship of independent variables with dependent variable.

\subsection{Population and Sampling}

The accurate sampling is reliant on the population's structure and the motivation behind the study (Bailey 1987). Author suggested many approaches to select the sample size, for example, rules of thumb, average size samples from earlier related researches, the statistical technique, or the technique where researchers are trying to investigate all they can afford (Bryman \& Bell, 2011). Thus, the researcher used the last approach for the current research. In order to select the sample Convenience sampling technique has been used. For testing hypotheses, a survey was organised to gather information from the sample. A questionnaire investigation was carried out to examine the influence of loyalty schemes) on client retention. For the current study, 120 questionnaires were distributed randomly among customers that were accessible. A total of 104 questionnaires were returned, which were used in this study thus achieving a response rate of $86.7 \%$.

\section{Data Analysis}

The data was processed, using SPSS software, for the quantitative analysis adopted in this study. The below discussion presents tables of Demographics, loyalty programs usage level, Correlation, Multicollinearity test, ANOVA test, Reliability test, Descriptive analysis and Multiple-regression analysis.

\subsection{Description of the study sample}

Table 1 proposes that a vast bit of the respondents has a place with female classification with $69.2 \%$, age classification from $21-30$ years of age with $78.8 \%$, larger part of them were understudies with $61.5 \%$, most of them were falling in the bachelor's category having $56.7 \%$, belonging to the income level PRs. 10,000-30,000 per month.

Table 1: Distribution of the Study Sample by Demographic Variables.

\begin{tabular}{llll}
\hline & & Frequency & Percent \\
\hline \multirow{3}{*}{ Gender } & $\mathbf{1}$ & 72 & 69.2 \\
& $\mathbf{2}$ & 32 & 30.8 \\
& Total & $\mathbf{1 0 4}$ & $\mathbf{1 0 0 . 0}$ \\
Age & $\mathbf{1}$ & 1 & 1.0 \\
& $\mathbf{2}$ & 82 & 78.8 \\
& $\mathbf{3}$ & 19 & 18.3 \\
& $\mathbf{4}$ & 2 & 1.9 \\
& Total & $\mathbf{1 0 4}$ & $\mathbf{1 0 0 . 0}$ \\
& $\mathbf{1}$ & 59 & 56.7 \\
\hline
\end{tabular}




\begin{tabular}{|c|c|c|c|c|}
\hline Journal of Business and Tourism & & & & $\begin{array}{l}\text { Volume } 04 \text { Number } 02 \\
\text { July - December, } 2018\end{array}$ \\
\hline & 2 & 34 & & 32.7 \\
\hline Education & 3 & 5 & & 4.8 \\
\hline & 4 & 5 & & 4.8 \\
\hline & 5 & 1 & & 1.0 \\
\hline & Total & 104 & & 100.0 \\
\hline & 1 & 90 & & 86.5 \\
\hline Marital Status & 2 & 14 & & 13.5 \\
\hline & Total & 104 & & 100.0 \\
\hline & 1 & 64 & & 61.5 \\
\hline & 2 & 27 & & 26.0 \\
\hline Occupation & 3 & 8 & & 7.7 \\
\hline & 4 & 4 & & 3.8 \\
\hline & Total & 104 & & 100.0 \\
\hline & 1 & & 16 & 15.4 \\
\hline & 2 & & 32 & 30.8 \\
\hline & 3 & & 24 & 23.1 \\
\hline Income & 4 & & 8 & 7.7 \\
\hline & 5 & & 8 & 7.7 \\
\hline & 6 & & 16 & 15.4 \\
\hline & Total & & 104 & 100.0 \\
\hline
\end{tabular}

The results from Table 2 further suggests that the point system card was frequently used $(51.0 \%)$ by the participants of research, tracked via Tier reward program $28.8 \%$, and Nonmonetary programs $20.2 \%$ respectively.

Table 2: Distribution of the study sample according to loyalty programs usage level.

\begin{tabular}{llll}
\hline & & Frequency & Percent \\
\hline \multirow{2}{*}{ Points program } & $\mathbf{1}$ & 53 & 51.0 \\
& $\mathbf{2}$ & 51 & 49.0 \\
Tier reward program & Total & $\mathbf{1 0 4}$ & $\mathbf{1 0 0}$ \\
& $\mathbf{1}$ & 31 & 28.8 \\
& $\mathbf{2}$ & 73 & 71.2 \\
Non-financial schemes & Total & $\mathbf{1 0 4}$ & $\mathbf{1 0 0}$ \\
& $\mathbf{1}$ & 20 & 20.2 \\
& $\mathbf{2}$ & 84 & 79.8 \\
& Total & $\mathbf{1 0 4}$ & $\mathbf{1 0 0 . 0}$ \\
\hline
\end{tabular}

\subsection{Pre-test Analysis}

To ensure the nature and fitness of the collected information the analyst utilized multiple regression and different statistical tools for testing hypothesis. Before testing hypothesis, the current study also conducted pre-test analysis, which were necessary for improving the quality of an academic research. From the findings of Pearson Correlation in Table 3, it suggests a strong relation at $(\alpha=0.01)$ among the variables, yet there is no absolute correlation among them, whereas $(.664 * *)$ was the strong value of Pearson correlation for the Point program and Non-monetary schemes. 
Table 3: Pearson Correlation amongst the (Points program, Tier Reward program, Non- monetary programs)

\begin{tabular}{|c|c|c|c|c|}
\hline \multicolumn{5}{|c|}{ Correlations } \\
\hline \multirow{4}{*}{ Points program } & & $\begin{array}{l}\text { Points } \\
\text { program }\end{array}$ & $\begin{array}{l}\text { Tier } \\
\text { reward } \\
\text { program }\end{array}$ & $\begin{array}{l}\text { Non- } \\
\text { monetary } \\
\text { schemes }\end{array}$ \\
\hline & Pearson Correlation & 1 & & \\
\hline & Sig. (2-tailed) & & & \\
\hline & $\mathrm{N}$ & 104 & & \\
\hline \multirow[t]{3}{*}{ Tier reward program } & Pearson Correlation & $.503^{* *}$ & 1 & \\
\hline & Sig. (2-tailed) & 0.000 & & \\
\hline & $\mathrm{N}$ & 104 & 104 & \\
\hline \multirow[t]{3}{*}{ Non-monetary schemes } & Pearson Correlation & $.664^{* *}$ & $.456^{* *}$ & 1 \\
\hline & Sig. (2-tailed) & 0.000 & 0.000 & \\
\hline & $\mathrm{N}$ & 104 & 104 & 104 \\
\hline
\end{tabular}

4.3 Multicollinearity test

The test was done to confirm that there is no multicollinearity among the Point program, Tier Reward program, Non- monetary programs. As presented in Table 4, the outcomes imply that the variance inflation factor regarding every factor was under (10), and the estimation of permitted tolerance for every factor was more than $(0.05)$ which affirms that there is no multicollinearity issue among the independent factors.

Table 4: Multicollinearity test

\begin{tabular}{lll}
\hline & \multicolumn{2}{l}{ Collinearity Statistics } \\
& Tolerance & VIF \\
\hline Points program & 0.509 & 1.966 \\
Tier reward program & 0.721 & 1.388 \\
Non-monetary schemes & 0.539 & 1.855
\end{tabular}

Linear relationship test concerning the independent factors (points program, Tier reward program and non-monetary schemes) and the dependent variable (client retention). The Scatter Plot demonstrates the confirmation of the primary pre-test to utilize linear regression analysis It revealed the utilization of the graphic interpretation of regression residual connection among the independent variables and the dependent variable. As the estimated normal means are right around (3.71) with the S.D of (0.867).

4.4 ANOVA Test

ANOVA analysis was performed to calculate multiple regression model's significance. As shown in Table 5, the significant $(0.000)$ is less than $(\alpha=0.05)$, which recommends the multi regression model to be used for hypotheses testing. 
Table 5: ANOVA Test

\begin{tabular}{|c|c|c|c|c|c|c|}
\hline \multicolumn{7}{|c|}{$\mathrm{ANOVA}^{\mathrm{a}}$} \\
\hline \multicolumn{2}{|c|}{ Model } & Sum of Squares & df & Mean Square & $\mathbf{F}$ & Sig. \\
\hline & Regression & 55.860 & 1 & 55.860 & 130.102 & $.000^{\mathrm{b}}$ \\
\hline & Residual & 43.794 & 102 & 0.429 & & \\
\hline & Total & 99.654 & 103 & & & \\
\hline \multirow[t]{3}{*}{2} & Regression & 69.317 & 2 & 34.658 & 115.385 & $.000^{\mathrm{c}}$ \\
\hline & Residual & 30.337 & 101 & 0.300 & & \\
\hline & Total & 99.654 & 103 & & & \\
\hline \multirow[t]{3}{*}{3} & Regression & 74.518 & 3 & 24.839 & 98.821 & $.000^{\mathrm{d}}$ \\
\hline & Residual & 25.136 & 100 & 0.251 & & \\
\hline & Total & 99.654 & 103 & & & \\
\hline
\end{tabular}

a. Dependent Variable: Customer Retention

b. Predictors: (Constant), Points

c. Predictors: (Constant), Points, Tier Reward

d. Predictors: (Constant), Points, Tier Reward, Non-monetary

\subsection{Reliability test}

Table 6 suggests that the scales have passed the reliability test because of the required Cronbach's alpha value which is 0.6 while that of the entire model is 0.85 , for the Point program is 0.83 , Tier reward program 0.87 , Non-monetary schemes 0.84 and customer retention is 0.78 . This confirms that the scales are acceptable for use.

Table 6: Values of Cronbach's Coefficient Alpha

\begin{tabular}{ll}
\hline & Cronbach's Alpha \\
\hline Points program & 0.83 \\
Tier reward program & 0.87 \\
Non-monetary schemes & 0.84 \\
Customer loyalty programs & 0.85 \\
Customer retention & 0.78 \\
\hline
\end{tabular}

4.6 Descriptive Analysis

Table 7 suggests that the mean for the survey responses were in the high zone of endorsement. The Tier reward program has the high mean of Mean $=4.38$ with $\mathrm{S}$. $\mathrm{D}=0.792$, trailed by Points Program Mean $=3.71$ with $\mathrm{S}$. D $=0.867$ lastly non-monetary programs Mean $=3.48$ with S. $\mathrm{D}=0.800$.

Table 7: Mean and S.D for research variables and components

\begin{tabular}{llll}
\hline Components & Mean & S. D & Level \\
\hline s4 & 3.49 & 1.441 & High \\
s5 & 3.26 & 1.461 & High \\
s6 & 3.32 & 1.450 & High \\
Points program & 3.71 & 0.867 & High \\
s7 & 4.18 & 0.890 & High \\
s8 & 4.03 & 1.074 & High \\
s9 & 3.97 & 1.178 & High \\
\hline
\end{tabular}




\begin{tabular}{|c|c|c|c|}
\hline \multicolumn{2}{|l|}{ Tournal of Business and Tourism } & \multicolumn{2}{|c|}{$\begin{array}{r}\text { Volume 04 Number } 02 \\
\text { July-December, } 2018\end{array}$} \\
\hline s10 & 3.48 & 1.174 & High \\
\hline s11 & 3.66 & 1.243 & High \\
\hline s12 & 3.38 & 1.409 & High \\
\hline Tier reward program & 4.38 & 0.792 & High \\
\hline s13 & 3.80 & 1.218 & High \\
\hline s14 & 3.87 & 1.223 & High \\
\hline s15 & 3.78 & 1.269 & High \\
\hline s16 & 3.61 & 1.202 & High \\
\hline s17 & 3.75 & 1.320 & High \\
\hline Non-monetary schemes & 3.48 & 0.800 & High \\
\hline s18 & 3.38 & 1.374 & High \\
\hline s19 & 3.35 & 1.275 & High \\
\hline s20 & 3.63 & 1.293 & High \\
\hline $\mathrm{s} 21$ & 3.48 & 1.207 & High \\
\hline $\mathrm{s} 22$ & 3.77 & 1.192 & High \\
\hline s23 & 2.82 & 1.335 & Medium \\
\hline Customer retention & 4.06 & 0.984 & High \\
\hline s24 & 3.93 & 1.100 & High \\
\hline s25 & 3.92 & 1.180 & High \\
\hline s26 & 3.84 & 1.263 & High \\
\hline s27 & 3.35 & 1.275 & High \\
\hline s28 & 3.63 & 1.293 & High \\
\hline s29 & 3.70 & 1.321 & High \\
\hline s30 & 3.59 & 1.405 & High \\
\hline s31 & 3.65 & 0.993 & High \\
\hline s32 & 3.76 & 1.203 & High \\
\hline loyalty programs & 3.71 & 0.867 & High \\
\hline Points program & 4.38 & 0.792 & High \\
\hline Tier reward program & 3.48 & 0.800 & High \\
\hline Non-monetary schemes & 4.06 & 0.984 & High \\
\hline Customer retention & 3.49 & 1.441 & High \\
\hline
\end{tabular}

4.7 Multiple Regression Analysis and Testing of Hypothesis

The researcher used multiple regression (see Table 8) to analyse the impact of loyalty schemes on client retention. Correlation coefficient were calculated at $(\mathrm{R}=0.865)$ among three loyalty schemes (independent factors) and client retention (dependent factor) and the coefficient of multiple determination was $\left(\mathrm{R}^{2}=0.74\right)$ demonstrating that $74 \%$ percent of client retention was portrayed by sub types of loyalty schemes and remaining affected percentage of different influencers are out of the consideration of the present examination. The current findings presented that the investigation is beneficial at $(\mathrm{F}=98.821)$ and (Significance $=0.000)$ at alpha $(\alpha=0.01)$. The entire model is helpful which reveals customer retention was affected by loyalty schemes. 
Table 8: Multiple Regression Coefficients

\begin{tabular}{|c|c|c|c|c|c|}
\hline \multirow[t]{2}{*}{ Model } & \multicolumn{2}{|c|}{$\begin{array}{l}\text { Unstandardized } \\
\text { Coefficients }\end{array}$} & \multirow{2}{*}{$\begin{array}{l}\text { Standardized } \\
\text { Coefficients } \\
\text { Beta }\end{array}$} & \multirow[t]{2}{*}{$\mathbf{t}$} & \multirow[t]{2}{*}{ Sig. } \\
\hline & B & Std. Error & & & \\
\hline (Constant) & 0.904 & 0.284 & & 3.183 & 0.002 \\
\hline Points program & 0.402 & 0.080 & 0.354 & 5.027 & 0.000 \\
\hline Tier reward program & 0.465 & 0.073 & 0.374 & 6.325 & 0.000 \\
\hline Non-monetary schemes & 0.382 & 0.084 & 0.311 & 4.549 & 0.000 \\
\hline
\end{tabular}

Table 8 proposes the effect of different kinds of loyalty schemes on customer retention: Point program $(t=5.027, \operatorname{Sig}=0.000)$, Tier reward program $(\mathrm{t}=6.325$, Sig=0.000), Non-monetary schemes $(\mathrm{t}=4.549, \mathrm{Sig}=0.000)$. The results reveal that customer retention was affected by all the specified reliability programs in this way, the analyst rejects the invalid theory and acknowledge all the elective speculation.

Table 9: Model Summary

\begin{tabular}{llllll}
\hline Model & R & R Square & $\begin{array}{l}\text { Adjusted } \\
\text { R Square }\end{array}$ & $\begin{array}{l}\text { Std. Error of the } \\
\text { Estimate }\end{array}$ & \begin{tabular}{l} 
Change Statistics \\
\cline { 5 - 5 }
\end{tabular} \\
\hline 1 & $.749^{\mathrm{a}}$ & 0.561 & 0.556 & 0.655 & 0.561 \\
2 & $.834^{\mathrm{b}}$ & 0.696 & 0.690 & 0.548 & 0.135 \\
3 & $.865^{\mathrm{c}}$ & 0.748 & 0.740 & 0.501 & 0.052
\end{tabular}

a. Predictors: (Constant), Points program

b. Predictors: (Constant), Point, Tier reward program

c. Predictors: (Constant), Point, Tier reward system, Non-monetary schemes

Table 9 indicates stepwise examination, the main impact was for Point program with estimated $\left(\mathrm{R}^{2}=56.1 \%\right)$, then point program and Tier reward program with $\left(\mathrm{R}^{2}=69.6 \%\right)$, finally the strong impact was for point program, tier reward program and Non-monetary schemes all together with $\left(\left(\mathrm{R}^{2}=74.8 \%\right)\right.$ respectively.

\section{Conclusion and Recommendations}

As indicated by the results of the current examination, all types loyalty schemes are helpful and significant in retaining customers. That concludes retaining customers is profitable because of loyalty schemes. Strong impact was observed for all types of loyalty schemes (Tier reward program, point program and Non-financial schemes) on retaining customers of hypermarkets in Pakistan.

Retailers must recognise how to modernize loyalty schemes that mirror the client's shopping behaviour, so as to hold them devoted to the end, thus turning a a walk-in purchaser into a valued customer. Based on our findings we recommend the following:

1. Retailers essentially offer all loyalty schemes because of their strong effect on retaining customers. Particularly the Tier reward program.

2. Retailers may need to invest in research for developing innovative techniques for developing or upgrading their loyalty schemes, which can attract new clients and raise the rate of shopping of the present customers. 
3. Retailers will essentially be centred on the harmony amongst expenses and incomes of each loyalty scheme since it is imperative for any business to think in a conservative technique.

4. Retailers can offer loyalty scheme which enable its users to change their collected points into concessions in a simplest way.

5. Retailers needs to concentrate on client retention as they the power to influence perceptions of their friends and family thus acts as their brand ambassadors. It is important to remind the reader that retaining old customers is less expensive than making new ones.

6. Develop a loyalty program which is most appropriate for youth desires and spending requirements.

7. Inform and persuade customers regarding all offered loyalty schemes and its subscription process.

8. Create a transparent feedback system, to better understand customer's opinions and suggestions regarding the offered loyalty schemes.

\section{Refrences}

Ali, J. F., \& Rehman, K. (2010). Determinants of consumer retention in cellular industry of Pakistan. African Journal of Business Management, 4(12), 2402-2408.

Anderson, E., Fornell, C., \& Lehmann, D. (1994). Customer Satisfaction, Market Share, and Profitability: Findings from Sweden. Journal of Marketing, 58(3), 53-66.

Aronkar, P., Jauhari, S., Bhakar, S. S., \& Lal, C. (2015). Effect of Customer Loyalty Program on Customer Retention: A Study of Organized Retail Sector in Gwalior Part-II Sample Research Papers. In S. S. Bhakar (Ed.), A Handbook on Writing Research Paper in Social Sciences (Part-II, pp. 48-59). Gwalior, India: ResearchGate.

Bailey, K. (1987). Methods of Social Research (3rd ed.). The University of Michigan: Free Press.

Barnes, J. (1997). Closeness, strength, and satisfaction: examining the nature of relationships between providers of financial services and their retail customers. Journal of Psychology and Marketing, 14(8), 765-790.

Bashir, S. (2011). Organizational Cynicism Development and Testing of an Integrated Model A Study of Public Sector Employees in Pakistan, 58-79.

Bolton, R., Kannan, P. K., \& Bramlett, M. (2000). Implications of Loyalty Program Membership and Service Experiences for Customer Retention and Value. Journal of the Academy of Marketing Science, 28(1), 95-108.

Brien, L., \& Jones, C. (1995). Do Rewards Really Create Loyalty? Harvard Business Review, 28(4), 130-130.

Bryman, A., \& Bell, E. (2011). Business Research Methods (3rd ed.). New York: Oxford University Press.

Deighton, J. (2000). Frequency Programs in Service Industries. In Teresa A. Swartz \& Dawn Iacobucci (Ed.), Handbook of Services Marketing \& Management (pp. 401-408). California 91320 United States: SAGE Publications, Inc. (1999).

Dictionary, B. (n.d.). What is non-monetary reward? Retrieved from http://www.businessdictionary.com/definition/non-monetary-reward.html

Dowling, G., \& Uncles, M. (1997). Do Customer Loyalty Programs Really Work? Sloan Management Review, 38(4), 01-24.

Drèzea, X., \& Hoch, S. (1998). Exploiting the installed base using cross-merchandising and category destination programs. International Journal of Research in Marketing, 15(5), 459471. 
Garcia, B. G., Arranz, A. G., \& Cillan, J. G. (2006). The role of loyalty programs in behavioral and affective loyalty. Journal of Consumer Marketing, 23(7), 387-396.

Gerpott, T., Rams, W., \& Schindler, A. (2001). Customer retention, loyalty, and satisfaction in the German mobile cellular telecommunications market. Telecommunications Policy, 25(4), 249-269.

Hallowell, R. (1996). The relationships of customer satisfaction, customer loyalty, and profitability: an empirical study. International Journal of Service Industry Management, 7(4), $27-42$.

Hennig-Thurau, T., \& Alexander, K. (1997). The Impact of Customer Satisfaction and Relationship Quality on Customer Retention: A Critical Reassessment and Model Development. Psychology \& Marketing, 14(8), 737-764.

Hofman-kohlmeyer, M. (2016). Customer Loyalty Program As a Tool of Customer Retention: Literature Review. CBU International Conference on Innovations in Science and Education, 4(762), 202-205.

Jain, R., \& Singhal, S. (2012). A conceptual model for exploring impact of loyalty programs on consumer purchase behavior: with special reference to Indian apparel retailers. International Journal of Research in Management \& Technology (IJRMT), 2(2), 164-172.

Karim, R. Al. (2011). Role of Loyalty Cards in Building Customer Retention in the Supermarket. D.U. Journal of Marketing, 4(1), 142-153.

Keaveney, S. (1995). Customer Switching Behavior in Service Industries: An Exploratory Study. Journal of Marketing, 59(2), 71.

Kopalle, P., \& Neslin, S. (2003). The economic viability of frequency reward programs in a strategic competitive environment. Review of Marketing Science, 1(1), 1-39.

Lewis, M. (2004). The Influence of Loyalty Programs and Short-Term Promotions on Customer Retention. Journal of Marketing Research, 41(3), 281-292.

Lin, J. C., \& Wu, C. (2011). The role of expected future use in relationship- based service retention. Managing Service Quality: An International Journal, 21(5), 535-551.

Magatef, S. G., \& Tomalieh, E. F. (2015). The Impact of Customer Loyalty Programs on Customer Retention. International Journal of Business and Social Science, 6(81), 78-93.

Mascarenhas, O., Kesavan, R., \& Bernacchi, M. (2006). Lasting customer loyalty: a total customer experience approach. Journal of Consumer Marketing, 23(7), 397-405.

Neira, C. V., Vázquez, R., \& Iglesias, V. (2010). Explaining customer satisfaction with complaint handling. International Journal of Bank Marketing, 28(2), 88-112.

Omar, N. A., Azrin, M., \& Sarah, H. (2009). What customers really want: exploring service quality dimensions in a retail loyalty program. UNITAR E-JOURNAL, 5(1), 68-76.

Peiguss, K. (2012). '7 Customer Loyalty Programs That Actually Add Value'. Retrieved from http://blog.hubspot.com/blog/tabid/6307/bid/31990/7-Customer-Loyalty.

Ranaweera, C., \& Prabhu, J. (2003). The influence of satisfaction, trust and switching barriers on customer retention in a continuous purchasing setting. International Journal of Service Industry Management, 14(4), 374-395.

Rowley, J. (2000). Product search in e-shopping: a review and research propositions. Journal of Consumer Marketing, 17(1), 20-35.

Rust, R., \& Zahorik, A. (1993). Customer satisfaction, customer retention, and market share. Journal of Retailing, 69(2), 193-215.

Rust, R., Zahorik, A., \& Keiningham, T. (1995). Return on Quality (ROQ): Making Service Quality Financially Accountable. Journal of Marketing, 59(2), 58-70.

Saeed, K., Grover, V., \& Hwang, Y. (2005). The Relationship of E-Commerce Competence to Customer Value and Firm Performance: An Empirical Investigation. Journal of Management Information Systems, 22(1), 223-256. 
Saunders, M., Lewis, P., \& Thornhill, A. (2009). Research Methods for Business Students (5th ed.). Edinburgh Gate Harlow Essex, England: Pearson Education Limited, 2009.

Sharp, B., \& Sharp, A. (1997). Loyalty Programs and their Impact on Repeat-purchase Loyalty Patterns. International Journal of Research in Marketing, 14(5), 473-486.

Singh, R., \& Khan, I. A. (2012). An Approach to Increase Customer Retention and Loyalty in B2C World. International Journal of Scientific and Research Publications, 2(6), 1-3.

Smith, M., \& Chang, C. (2009). The impact of customer-related strategies on shareholder value: evidence from Taiwan. Asian Review of Accounting, 17(3), 247-268.

Sneath, R., \& Lacey, J. (2006). Customer loyalty programs: are they fair to consumers? Journal of Consumer Marketing, 23(7), 458-464.

Solarová, P. (2015). Loyalty programs of selective grocery retailers in the Czech republic. Acta Universitatis Agriculturae et Silviculturae Mendelianae Brunensis, 63(2), 617-625.

Steenkamp. (1989). Product Quality, An investigation into the concept and how it is perceived by consumers. Steenkamp.

Tabaku, \& Mersini. (2015). Romanian economic and business review. Romanian Economic Business Review, 10(2), 71-86.

Udin, H., \& Hizza, I. (2014). Factors Influencing Customer Satisfaction and E-Loyalty: Online Shopping Environment among the Young Adults Izyan. Management Dynamics in the Knowledge Economy, 2(3), 462-471.

Uncles, M., Dowling, G., \& Hammond, K. (2003). Customer loyalty and customer loyalty programs. Journal of Consumer Marketing, 20(4), 294-316.

Verhoef, P. (2003). Understanding the Effect of Efforts on Customer Retention and Customer Share Development. Journal of Marketing, 67, 30-45.

Vinod, B. (2011). 'Unleashing the power of loyalty programs'. Journal of Revenue and Pricing Management, 10(5), 471-476.

Vyas, P., \& Sinha, P. (2008). Loyalty Programmes: Practices, Avenues and Challenges. ResearchGate, 12(1), 2-23.

Waarden, L. M. (2006). The influence of loyalty programme membership on customer purchase behaviour. European Journal of Marketing, 42(1/2), 87-114.

Wood, A. (2005). Loyalty-What can it really tell you? Database Marketing and Customer Strategy Management, 13(1), 55-63.

Wright, C., \& Sparks, L. (1999). Loyalty saturation in retailing: exploring the end of retail loyalty cards? International Journal of Retail \& Distribution Management, 27(10), 429-440.

Yang, Z., \& Peterson, R. (2004). Customer perceived value, satisfaction, and loyalty: The role of switching costs. Psychology and Marketing, 21(10), 799-822. 